\title{
Evaluation of the Protective Effects of Ellagic Acid and Taurine on Lipid Profile and Gene Expressions of NF-KB, IL-1 $\beta$, and TNF-a against Fluoxetine Induced Hepatotoxicity in Male Wistar Rats
}

Research Article

Keywords:

Posted Date: April 9th, 2021

DOI: https://doi.org/10.21203/rs.3.rs-300376/v2

License: (1) This work is licensed under a Creative Commons Attribution 4.0 International License.

Read Full License 


\section{Abstract}

The authors have requested that this preprint be withdrawn due to erroneous posting.

\section{Full Text}

The authors have withdrawn this preprint from Research Square. 